\title{
Prevention of Crop Damage Caused by Blackbirds
}

\section{by E. A. Hurd*, Canada Dept. of Agriculture Experimental Farm, Regina}

\begin{abstract}
How can we appreciate the beauty of the Yellow-headed Blackbirds when they rob us and time after time destroy experimental plots representing a year's hard work? This has been the problem facing the staff of the Regina Experimental Farm for years. Rather than being admired, this defiant bird has been cursed as much as the yellow dandelion in our lawns. Man has learned to control the dandelion, but the prevention of damage by iblackbirds requires negotiations on their terms.
\end{abstract}

For many years the cereal variety tests at Regina have been located along the south side of Regina Waterfowl Park which is a bird sanctuary. Much of the shallow creek area bordering on the Experimental Farm is grown up with cattails which make it an ideal nesting place for blackbirds. As crops commence to mature these birds begin to feed on the earliest varieties. Yellow-headed Blackbirds are the most common at this location, but the Redwinged Blackbird and other species are also harmful when present. A flock of blackbirds can destroy a variety test in one day. Protection of the tests by using a shotgun was tried but was unsuccessful, although one employee bragged of killing as many as 14 birds with one shot. Since blackbirds do not scare easily, it would be necessary for someone to be in the field with a gun from daylight until dark for a period of six weeks. While permission has been obtained for shooting destructive birds in the experimental plots, it is dangerous in or near the city.

In a search for protection from various kinds of birds, several research stations in the United States and Canada have developed high voltage electric bird control apparatuses (Grant and Wells, 1957; Pfeifer, 1956). The principle they use is to string two wires two or three inches apart on poles around a test area. Short pieces of 'wire are placed at reguiar intervals in such a way that they do not quite connect the two main wires. The high voltage causes continuous arcing and any birds that sit on the wire short-circuit the system and are electrocuted. Only a very few have been killed but the crackling noise caused by the arcing scares the blackbirds away. Complete control has been maintained within the enclosed area and some control has occurred for 50 or 100 feet outside of the wire. Although this method is effective it is only practical for a small area of valuable material. The cost is high per unit area and the poles are a nuisance and unsightly.

For these reasons, additional control methods have been sought. Trap or lure strips for the birds to feed on have been planted along the edge of the lake for several years. These are sown earlier than the test plots using a mixture of early maturing varieties of wheat and oats. The strips are one-quarter of a mile long and nine feet wide, with three foot strips sown side by side in three successive weeks. The birds are also allowed to feed on an additional area of two acres which has been seeded each year as demonstration plots. These plots include over 100 varieties of wheat, oats, barley and flax with a wide range of maturity dates. This provides material at an attractive stage to the birds over a long period of time. Since the grain from these plots is not required and their demonstration value is past at maturity no loss results.

This method of controlling damage appeared to be adequate until 1961 when the dry conditions were responsible for failure of the lake strip.

\footnotetext{
*Editor's Note: Dr. Hurd is a specialist in cereal crops and has been conducting research for-better varieties for many years at Regina. Since the University of Saskatchewan, Regina Campus, will shortly displace the Experimental Farm. Dr. Hurd's relocated plots will probably not suffer from the same extensive depredation problems as at present. However, the experiments which he has undertaken to control blackbirds will be of considerable interest to workers in other regions, for blackbird depredation is a problem of international concern. Both the Canadian Wildlife Service and the U.S. Fish and Wildlife Service are presently enqaged in studies of blackbird control methods.
} 
Another division of experimental work at the Farm put up scare-crows on the range next to the demonstration plots thus chasing the blackbirds into the cereal variety tests where a great deal of damage was done. Damage was particularly severe in 1961 because of the thin crops and increased number of birds.

As long as the blackbirds get all the ripening grain they can eat near their nesting area they will leave experimental plots alone. However, sunflowers are the exception. If there are sunflowers within a mile or two the blackbirds will feed on them in preference to grain crops. The only way to grow sunflower variety tests is the tedious covering of each head after it flowers with a waxedpaper garbage bag. Even then the birds tear some bags and get at the maturing heads.

While the provision of lure or feeding strips seems to be the most prac- tical means of preventing damage, it is not positive. For this reason the high voltage apparatus will be maintained for the most valuable material. In addition the Experimental Farm is planning to invest in acetylene exploders and strings of firecrackers which can be used as emergency measures. These make a loud bang every few minutes and provide a continuous scare.

By combining a number of methods of preventing crop damage it maý be possible for us to live in harmony with the yellow-headed birds. Who knows, we may even learn to appreciate their aesthetic value!

\section{LITERATURE CITED}

Grant, M. N., and S. A. Wells. 1957. Bird damage control at Lethbridge. Cereal News, 3 (1): 5-8

Pfeifer, P. 1956. A bird control apparatus for experimental plots. Agron. Jour., 48: 139141.

\title{
Mockingbird at Fort Qu'Appelle
}

\author{
by E. M. Callin, Fort San
}

I suppose most bird-watchers have a few "check-points"-good spots that are most accessible and can be visited even if only a few minutes are available. They are especially useful and rewarding during migration.

One of my favourite check-points is the dam over the river at Fort Qu'Appelle for there, in a very small space, are river, lake, marsh, large trees and shrubs. On May 18, 1962, as I made a detour to this area, a bird flew up in front of the car and settled in some near-by willows. The unusual pattern and shape of the wings and tail immediately marked it as a stranger and moments later I was viewing through my binoculars the first.Mockingbird I had ever seen. At first it was lightly screened by the willows but during the next ten minutes or so I had an unobstructed view as it moved from tree to tree, then flew to the ground and proceeded to feed.

The actions of the bird while ground feeding were quite interesting and unusual; each time it moved forward the wings were spread and raised to the approximate level of the back. Though a pale and comparatively colorless bird when at rest, a surprising transformation occurred when the expanded wings flashed boldly with white. In this respect it reminded one of the Willet and of the Shrikes.

The Mockingbird is a rarity in Saskatchewan. There are few records for the province and, although I have records of over 20 observers in respect for the Qu'Appelle-Valley and adjoining area, with some of the records dating back for 100 years, there are yet only four records for this area (all of them within the last five years).

\section{EARLY RECORD OF GYRFALCON NEAR REGINA}

by Thomas E. Randall, Edmonton

The following old note from my journal may be worth recording. On December 12, 1912, while I was crossing a field on our farm four.miles from Drinkwater (about 25 miles southwest of Regina) a white-phase Gyrfalcon flew over my head so close that the black spotting could be clearly seen. 